JPRO

Vol. 1 No. 12020

\title{
EMOSI KONSUMEN DALAM MENDUKUNG KEPUASAN PEMBELIAN SECARA ONLINE DI MASA PANDEMI COVID 19
}

\author{
Lesy Cornella' ${ }^{1}$, Dedi Rianto Rahadi ${ }^{2}$ \\ President University, Indonesia
}

Corresponding Author:

Nama Penulis: Lesy Cornella

E-mail: lesycornella@gmail.com

\begin{abstract}
:
Emotions are things that cannot be measured from human behavior, because every human being must have emotions, both negative emotions and emotions. At this time, many considerations are made when buying an item, one of which is the emotional factor. Consumer emotions have become unstable due to the plague that hit Indonesia, namely the Covid 19 outbreak. This pandemic has caused several activities to stop, one of which is the ban on crowding. Currently, purchases are mostly made online, as evidenced by the increasing number of online shopping application users. Even though the purchase is made online, satisfaction is still considered in order to maintain a good customer relationship. The study used a qualitative method of interviewing. By using this method, it is hoped that the research will be more focused and the results obtained are in accordance with the facts that occur. The results showed that consumer emotions were one of the supporting factors for online purchase satisfaction during the Covid 19 pandemic.
\end{abstract}

Keywords: Emotions, consumers, buyer satisfaction, covid 19 pandemic

\begin{abstract}
Abstrak:
Emosi adalah hal yang tidak bisa dipisahkan dari tingkah laku manusia, karena setiap manusia pasti memiliki emosi baik itu emosi positif maupun emosi negatif. Pada masa ini, banyak pertimbangan yang dilakukan ketika akan membeli suatu barang salah satunya adalah faktor emosi. Emosi konsumen menjadi tidak stabil akibat wabah yang melanda Indonesia yaitu wabah covid 19. Pandemi ini menyebabkan beberapa kegiatan terhenti, salah satunya adalah larangan berkerumun. Saat ini pembelian lebih banyak dilakukan secara online, terbukti dari jumlah pengguna aplikasi belanja online yang terus meningkat. Meskipun pembelian dilakukan secara online, namun kepuasan tetap diperhatikan agar tetap terjalin customer relationship yang baik Penelitian ini menggunakan metode kualitatif dengan cara melakukan wawancara. Dengan menggunakakan metode tersebut diharapkan penelitian menjadi lebih terarah dan hasil yang didapatkan pun sesuai dengan fakta yang terjadi. Hasil penelitian menujukkan bahwa emosi konsumen menjadi salah satu faktor pendukung kepuasan pembelian secara online di masa pandemi covid 19
\end{abstract}

Kata kunci: Emosi, konsumen, kepuasan pembeli, pandemi covid 19 


\section{PENDAHULUAN}

Pada saat ini, Indonesia dan sebagian negara lainnya banyak yang terkena dampak negatif akibat adanya wabah yang menyerang saat ini, yaitu Covid 19 atau biasa disebut virus corona. Covid 19 atau yang lebih dikenal dengan nama virus Corona adalah suatu virus yang menyerang Indonesia pada awal maret dan virus ini dapat mematikan. Sudah sekitar 7 bulan sejak virus itu menyerang Indonesia banyak kerugian yang terjadi, banyak toko-toko maupun perusahaan yang tutup karena tidak adanya pemasukan. Perekonomian di dunia pun mulai menurun, pada kuartal pertama tahun 2020, pertumbuhan ekonomi mitra dagang Indonesia negatif: Singapura -2,2, Hong Kong -8,9, UE -2,7 dan Cina semuanya turun menjadi 6,8. Indonesia mengalami kontraksi yang cukup signifikan, dari 4,97 pada triwulan IV tahun 2019 menjadi 2,97 pada triwulan I tahun 2020. Indonesia telah melakukan berbagai upaya untuk menstabilkan perekonomian, salah satunya dengan menetapkan normal baru.

Perusahaan yang mengalami kerugian akibat gerai tokonya sepi melakukan strategi penjualan dengan cara online. Jual beli online merupakan aktivitas jual beli yang dilakukan tanpa melalui kontak fisik, pembeli dan penjual tidak harus bertemu untuk bernegosiasi dan bertransaksi, pembeli dan penjual dapat berkomunikasi melalui alat komunikasi maupun platform digital seperti instagram, whatsapp, shopee, tokopedia, bukalapak, dan lain-lain.

Pada saat ini banyak perusahaan yang mulai membuka online store agar proses jual beli tetap terjadi meskipun tidak dilakukan secara tatap muka. Dengan adanya online store memudahkan pelanggan untuk membeli suatu barang tanpa harus keluar rumah dan tetap menjalani social distancing. Ketika seseorang terlalu sering berdiam diri, emosi mereka biasanya menjadi kurang stabil. Perasaan intens yang dirasakan dan diarahkan pada seseorang atau sesuatu disebut dengan emosi. Pada saat yang sama, perasaan yang tidak memiliki emosi yang kuat dan biasanya muncul tanpa peristiwa tertentu sebagai rangsangan disebut mood atau suasana hati (Rahadi, 2020:119).

Emosi lebih cepat datang dibanding mood, hal ini dipercayai oleh sebagian para ahli. Contohnya, ketika seseorang bertindak kasar pada kita, secara reflek 
Vol. 1 No. 12020

kita akan merasa marah dan sedih akan sikap tersebut. Emosi adalah perasaan intens yang datang dan pergi dengan cepat dalam hitungan menit bahkan hitungan detik. Suatu hari kita dihadapkan dengan suasana hati yang buruk dengan segera kita juga akan merasakan sedih bahkan bahagia. Karena persepsi situasinya, sifat dan intensitas emosi biasanya berkaitan. Emosi dapat dikendalikan dengan cara mencari pengetahuan yang mendalam mengenai emosi itu sendiri.

Emosi tidak selamanya buruk, karena ketika kita bahagia maka kita akan merasakan emosi yang positif, begitupula ketika kita merasakan relaxed. Ketika kita akan membeli suatu barang biasanya kita akan dipengaruhi oleh emosi, ketika suasana hati sedih otomatis konsumen akan malas membeli sesuatu, seseorang akan senang melakukan apapun apabila mood atau keadaan hatinya sedang baik-baik saja.

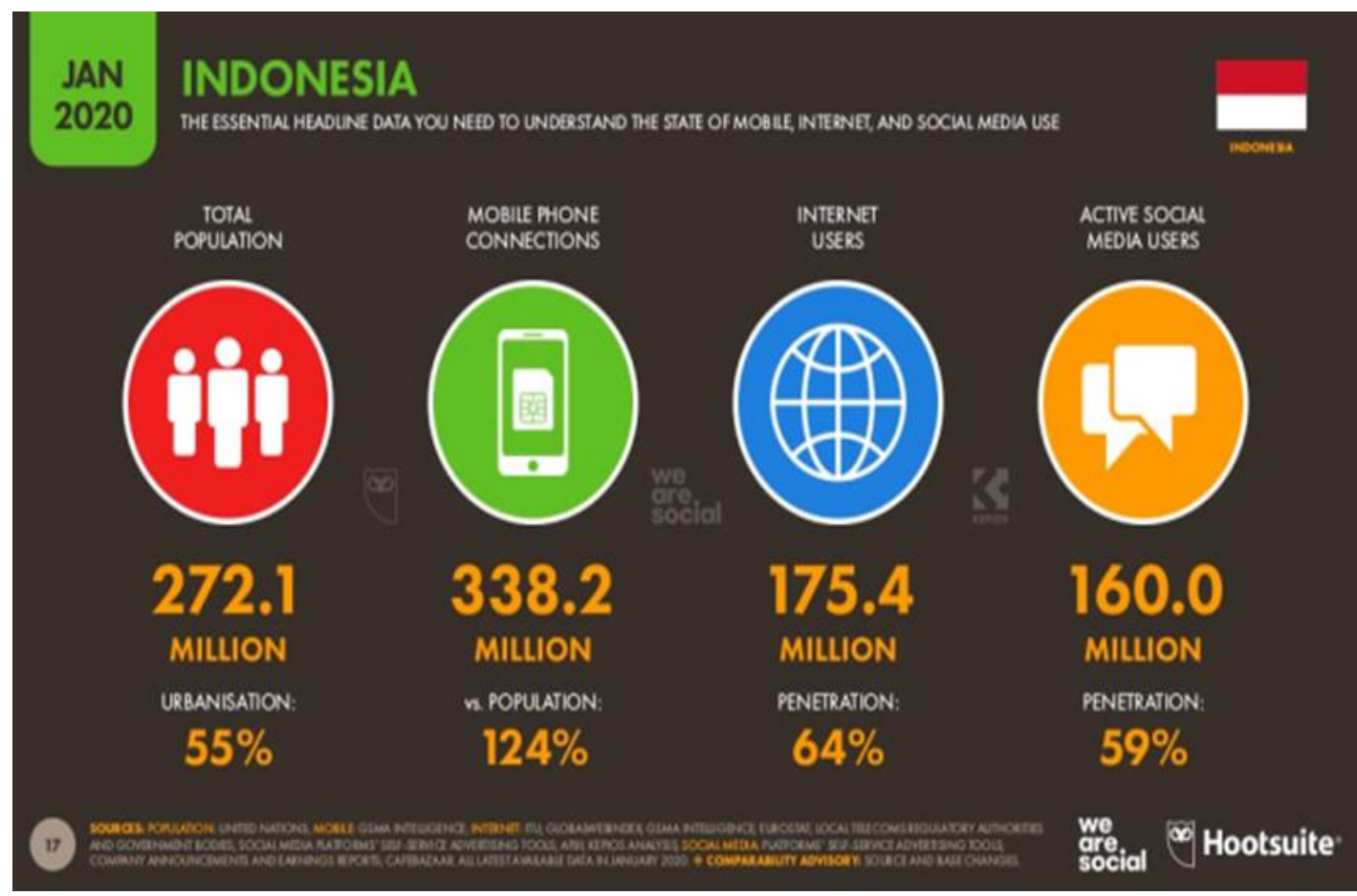

Gambar 1. Data penggunaan mobile internet dan penggunaan media social

Jika dilihat dari data diatas bisa kita simpulkan bahwa penggunaan mobile phone sangat tinggi, maka hal itu membuat masyarakat lebih aktif di sosial media. Saat ini, kebanyakan pembelian dan penjualan dilakukan secara online. Karena kita tidak harus bersusah payah keluar rumah, segala sesuatunya dapat 
Vol. 1 No. 12020

dibeli dengan cara online melalui smartphone. Pembelian secara online selain praktis juga dapat mendukung pemerintah dalam program dirumah saja apabila tidak ada urusan yang mendesak. Masyarakat berbelanja di online store untuk membeli kebutuhannya karena biasanya harga di online store lebih murah dibanding offline store, karena penjual di online store tidak harus mengeluarkan uang untuk menyewa toko dan membayar beban lainnya. Online store banyak digunakan oleh masyarakat, buktinya adalah iPrice Group menempatkan Tokopedia sebagai aplikasi belanja online dengan pengunjung web bulanan terbanyak di kuartal ketiga tahun 2019. Jika ditotal jumlah pengunjung aplikasi bulanan Tokopedia adalah 66 juta.

Peringkat selanjutnya adalah Shopee dengan total pengunjung 56 juta, dan peringkat selanjutnya adalah Bukalapak dengan total 43 juta per bulan Selain karena kebutuhan, masyarakat membeli barang-barang secara online dipengaruhi oleh beberapa faktor, yaitu harga, tingkat kepercayaan, keleluasaan waktu, dan produk yang bervariasi. Jika harga yang dijual lebih murah maka pelanggan pun akan puas. Pada saat ini aplikasi e-commerce menerapkan fitur chat yang bisa memudahkan pembeli untuk menanyakan barang tersebut. Jadi, meskipun pembelian dilakukan secara online namun kepuasan pelanggan tetap harus diperhatikan karena pelanggan yang puas akan semakin loyal, kurang sensitif terhadap harga, dan memberikan review yang baik kepada perusahaan (Dasmawita, 2016)

Berdasarkan latar belakang yang sudah diuraikan di atas, dengan begitu dapat dirumuskan masalahnya yaitu bagaimana emosi konsumen dapat dalam mendukung kepuasan pembelian secara online di masa pandemi covid 19?

\section{METODE PENELITIAN}

Metode yang digunakan adalah metode kualitatif. Metode kualitatif yakni penelitian untuk mengamati perilaku sosial, manusia atau obyek yang diteliti melalui pengamatan langsung secara alamiah untuk memperoleh informasi yang valid serta dilaporkan dalam bentuk narasi atau tulisan melalui pendekatan ilmiah. Ada dua tujuan utama dalam penelitian kualitatif, yaitu: 
Vol. 1 No. 12020

menjabarkan serta mengungkapkan sesuatu (to descibe and explore), dan menjabarkan serta menjelaskan sesuatu (to describe and explain). Rahadi (2020:4) mengemukakan bahwa metode penelitian kualitatif lebih cenderung mengkaji permasalahan secara case by case karena permasalahan selalu berbeda dengan permasalahan lainnya serta tidak dapat digeneralisasi dan berfungsi memberikan kategori substantive.

Definisi lain juga mengemukakan bahwa penelitian kualitatif yaitu penelitian yang memanfaatkan wawancara terbuka untuk menelaah dan memahami sikap, perasaan, pandangan, dan perilaku individu. Pada penelitian ini, peneliti melakukan wawancara dengan mengumpulkan sampel sebanyak 5 orang yang berprofesi sebagai karyawan, ibu rumah tangga, mahasiswa, dan juga pedagang. Dengan tujuan untuk menganalisa tentang emosi konsumen dan kepuasan pembelian secara online di masa pandemi covid 19.

\section{HASIL PENELITIAN}

Berdasarkan penelitian yang telah dilakukan, penulis mengambil sampel sebanyak 5 orang, yang berprofesi sebagai ibu rumah tangga, pelajar, dan juga karyawan swasta. Masing-masing memiliki jawaban yang hampir mendekati sama tentang hal tersebut. Penulis menanyakan apakah emosi mendorong keinginan untuk melakukan pembelian? Semua responden menjawab iya. Kemudian pertanyaan kedua, penulis menanyakan mengapa emosi konsumen dapat memengaruhi kepuasan pada saat berbelanja online?

Beberapa informan menjawab karena emosi sangat berpengaruh pada tingkah laku dan kepuasan pada saat membeli suatu produk. Karena apabila suasana hati sedang sedih kemudian penjual memberi pelayanan yang memuaskan maka customer pun akan merasa senang. Selanjutnya pertanyaan ketiga, apa yang memengaruhi kepuasan pembelian pada saat membeli barang secara online? Sebagian informan menjawab hal yang memengaruhi kepuasan adalah sikap penjual dan rate pada toko. 


\section{PEMBAHASAN}

\section{Pengaruh Emosi Terhadap Kepuasan Konsumen}

Krisis ekonomi yang terjadi pada saat ini disebabkan oleh pandemi covid 19, karena tidak sedikit masyarakat yang dengan paksa kehilangan pekerjaannya. Tidak sedikit juga para pedagang yang mengalami penurunan omset karena para pembeli banyak yang terkena phk.

Hal ini membuat emosi konsumen menjadi tidak stabil, emosi dapat mempengaruhi kepuasan konsumen, karena ketika emosi kita tidak stabil maka hati dan pikiran pun akan merangsang hal terssbut yang menyebabkan kita akan selalu merasa kesal terhadap sesuatu. Kepuasan dapat terjadi apabila emosi konsumen stabil dan penjual dapat meningkatkan suasana konsumen. Contohnya adalah ketika konsumen merasa sedih kemudian ia melihat discount yang ditawarkan penjual secara besar-besaran, maka konsumen itu akan merasa senang dan merasa puas karena hal tersebut. Kepuasan tidak bisa ditunggu, namun bisa diciptakan.

Penjual harus selalu mencari cara agar membuat konsumen puas apabila belanja di toko tersebut. Karena apabila ekspetasi konsumen terpenuhi maka konsumen pun akan puas bahkan menjadi loyal terhadap toko penjual. Hal itu membuktikan bahwa emosi sangat berpengaruh terhadap kepuasan konsumen, pada saat pandemi seperti saat ini segala hal dilakukan secara online, tidak lagi dilakukan dengan cara offline.

Sejak pandemi maret lalu para perusahaan sempat mengalami keterpurukan karena covid 19, namun dengan adanya platform digital ecommerce seperti shopee, tokopedia, bukalapak perusahaan dapat bangkit dari keterpurukan. Barang-barang kebutuhan pokok dan juga kebutuhan tambahan sudah banyak dijual di e-commerce. Dengan adanya e-commerce sangat membantu para perusahaan maupun para penjual online shop yang baru merintis usaha.

Pada saat ini, yang dirugikan tidak hanya perusahaan besar, tetapi para pedagang juga. Karena masyarakat menjadi takut untuk keluar rumah karena adanya virus tersebut, hal itu membuat para pedagang mengalami kerugian 
Vol. 1 No. 12020

yang signifikan. Dengan adanya online store sangat membantu proses jual beli masyarakat, masyarakat bisa dengan mudah membeli segala sesuatunya melalui gawai yang mereka miliki dan hal itu adalah hal yang praktis sehingga membuat konsumen senang karena tidak harus keluar rumah.

\section{Pengaruh Emosi Pada Daya Beli Masyarakat Secara Online}

Menurut Park et al. (2005) Emosi merupakan pengaruh dari mood dan faktor penting bagi konsumen untuk mengambil keputusan pembelian. Emosi berfungsi memotivasi orang untuk terlibat dalam tindakan-tindakan penting agar dapat bertahan hidup. Menurut salah satu partisipan yang penulis wawancarai, ia selalu membeli barang-barang yang ia sukai ketika hatinya merasa senang dan ia selalu antusias apabila platform belanja online memberi potongan ongkir kepada pembeli, terlebih lagi apabila pelayanan yang diberikan oleh penjual berkualitas sehingga dapat meningkatkan kepuasan konsumen. Dengan begitu, kepuasan konsumen akan terpenuhi

Yang nantinya memberikan dampak terhadap kestabilan emosi konsumen. Sedangkan, ketika pembeli merasakan emosi negatif daya tingkat keinginan membeli akan menurun. Pelayanan yang diberikan dengan sungguhsungguh pasti akan membuat konsumen menjadi tertarik untuk terus berbelanja di toko tersebut. Relationship antara penjual dan pembeli memang sangat penting untuk keberlangsungan proses jual beli.

\section{Kepuasan Konsumen Secara Online}

Pada masa ini, online adalah teman terbaik. Karena segala sesuatunya selalu dilakukan secara online. Konsumen akan merasa puas apabila penjual melakukan pelayanan yang baik. Pelayanan merupakan sikap atau cara penjual melayani kepada konsumen, sehingga konsumen merasa dihargai, dihormati dan dipuaskan(Tjiptono, 2012). Kepuasan konsumen pun dapat dinilai secara online karena pada aplikasi e-commerce disediakan fitur rating, komplain, dan juga pengajuan dana apabila barang yang dibeli tidak sesuai dengan ekspetasi konsumen. Pembeli biasanya percaya membeli online apabila toko tersebut dapat meyakinkan pembeli. Karena meskipun dilindungi oleh aplikasi ecommerce tetap saja banyak penipuan seperti barang palsu yang dilakukan 
Vol. 1 No. 12020

oleh oknum yang tidak bertanggung jawab. Namun masih banyak sekali penjual yang selalu mengedepankan pelayan dan performa toko untuk menarik pembeli.

Dengan demikian konsumen akan tetap merasa puas meskipun berbelanja secara online. Konsumen akan memberikan rating rendah apabila pengemasan yang dilakukan oleh penjual lama, packingan tidak rapih, dan juga ekspedisi pengiriman juga lama. Oleh karena itu, pembeli harus tepat dan cepat dalam memilih kemasan yang akan digunakan, harus cepat ketika mengemasi barang, dan juga harus membangun hubungan yang baik dengan konsumen. Contohnya dengan cara menanyakan produk tersebut setelah berada ditangan penjual, atau bisa juga dengan cara mengirimkan thankyou card di kemasan kepada pembeli. Hal tersebut pasti akan membuat konsumen menjadi senang karena merasa diperhatikan dan dilayani dengan sungguh-sungguh.

\section{KESIMPULAN}

Dari hasil penelitian jurnal ini dapat disimpulkan bahwa covid 19 tidak menjadi penghalang proses jual beli karena segala sesuatunya dapat dibeli melalui online shop. Emosi konsumen dapat memengaruhi tingkat daya beli masyarakat, karena semenjak covid 19 masyarakat banyak yang sedih karena kehilangan pekerjaannya dan ia juga tidak dapat membeli barang secara offline. Keberadaan online shop sangat memudahkan konsumen, karena konsumen tidak harus berkerumun untuk membeli barang yang ia ingin beli, karena segala sesuatunya bisa dilakukan dengan cara mudah melalui intenet.

Emosi konsumen dapat mempengaruhi daya beli konsumen karena segala tindakan pasti disertai oleh emosi. Emosi tidak selamanya buruk, karena emosi memiliki banyak ragamnya seperti, bahagia, sedih, takut, lelah, terkejut, dan lain-lain. Ketika konsumen memilih untuk berbelanja online, konsumen tetap dalam pelayanan yang baik dari para penjual karena apabila konsumen tidak paham tentang barang tersebut atau ingin menanyakan hal lain, telah disediakan fitur chat. Apabila berbelanja di aplikasi social media seperti instagram ataupun whatsapp pun konsumen bisa menanyakan langsung 
melalui direct message ataupun chat.

Berdasarkan simpulan dari hasil penelitian, maka dapat disimpulkan saran yaitu, penjual seharusnya selalu mengedepankan performa toko agar pembeli menjadi yakin dan percaya jika membeli ditoko penjual. Dan penjual harus selalu mengedepankan untuk memberi kepuasan kepada konsumen. Contohnya ketika konsumen mengirim pertanyaan, sebisa mungkin penjual harus fast respond agar pembeli pun merasa puas. Karena apabila konsumen puas maka konsumen itupun akan selalu berbelanja di toko itu lagi dan dapat meningkatkan penjualan.

\section{REFERENSI}

Az-Za'balawi, M. S. (2007). Pendidikan Remaja Antara Islam \& Ilmu Jiwa. Gema Insani.

Bahri, B. (2018). Keputusan Pembelian dan Kepuasan Konsumen Dipengaruhi Variabel Lokasi, Pelayanan, Kualitas Produk, Nilai Emosional, dan Disain Interior yang Berdampak pada Tingkat Pembelian. Jurnal Maksipreneur: Manajemen, Koperasi, dan Entrepreneurship, 8(1), 60-80.

Churiyah, M. (2011). Pengaruh konflik peran, kelelahan emosional terhadap kepuasan kerja dan komitmen organisasi. Jurnal Ekonomi Bisnis, 16(2), 145-154.

Dasmawita, Y. (2016). Analisis Kualitas Pelayanan Kesehatan Bagi Pemilik Kartu Badan Penyelenggara Jaminan Sosial (BPJS) Dirumah Sakit Umum Daerah (RSUD) Arifin Achmad Provinsi Riau (Doctoral dissertation, Universitas Islam Negeri Sultan Syarif Kasim Riau).

Goleman, D., Boyatzis, R. E., \& McKee, A. (2002). Primal leadership: Realizing the power of emotional intelligence. Harvard Business Press.

Hetharie, J. A. (2012). Peran emosi positif sebagai mediator stimulus lingkungan toko dan faktor sosial terhadap impulse buying tendency pada Matahari Departement Store Kota Ambon. Jurnal Aplikasi Manajemen, 10(4), 890898.

Kusumawati, D., \& Saifudin, S. (2020). Pengaruh Persepsi Harga Dan Kepercayaan terhadap Minat Beli Secara Online Saat Pandemi Covid-19 pada Masyarakat Millenia di Jawa Tengah. JAB (Jurnal Akuntansi \& Bisnis), $6(01)$. 
Sukmadinata, N. S. (2005). Landasan psikologi proses pendidikan.

Oktaviani, W. (2014). Pengaruh Kualitas Layanan, Emosional Pelanggan, dan Kemudahan Terhadap Loyalitas Melalui Kepuasan Pelanggan. Jurnal Ilmu Manajemen (JIM), 2(1).

Park, E.J.,Kim,Eun Yong.,and Forney,J.C. (2005). A Structural Model of Fashion Oriented Impulse

Perilaku belanja online Di Indonesia. (2019, August 23). BINUS UNIVERSITY BANDUNG - Kampus Teknologi https://binus.ac.id/bandung/2019/08/perilaku-belanja-online-diindonesia/

Buying Behavior. Journal of Fashion Marketing and Manajement 10 (4): 433446

Permana, M. V. (2013). Peningkatan Kepuasan Pelanggan melalui Kualitas Produk dan Kualitas Layanan. JDM (Jurnal Dinamika Manajemen), 4(2).

Puirih, K., Mananeke, L., \& Lengkong, V. P. (2020). Fenomena Keputusan Pembelian Dan Penggunaan Media Sosial Terhadap Kepuasan Konsumen Tokopedia Di Kota Manado. Jurnal EMBA: Jurnal Riset Ekonomi, Manajemen, Bisnis dan Akuntansi, 8(3).

Rahadi, d. R., \& Susilowati, E. (2019). Perilaku Organisasi : Konsep dan Implementasi (1st ed.). PT. Filda Fikrindo.

Rahadi, D. R. (2020). Konsep Penelitian Kualitas Plus Tutorial NVivo.

Sudarso, E. (2016). Kualitas Layanan, Nilai Fungsional, Nilai Emosional, dan Kepuasan Konsumen: Sebuah Studi Kasus. Jurnal Ekonomi Bisnis dan Kewirausahaan (JEBIK), 5(3), 165-178.

Sugianto, D. (2020, June 1). Sederet Alasan RI Butuh new normal. detikfinance. https://finance.detik.com/berita-ekonomi-bisnis/d-5036585/sederetalasan-ri-butuh-new-normal/2

Tjiptono, Fandy dan Gregorius Chandra, 2012, Pemasaran Strategik, Yogyakarta, ANDI. 